\title{
EXHALED BREATH CONDENSATE pH IN ADULT CROATIAN POPULATION WITHOUT RESPIRATORY DISORDERS: HOW HEALTHY A POPULATION SHOULD BE TO PROVIDE NORMATIVE DATA?
}

\author{
Veda M. VARNAI, Anita LJUBIČIĆ ĆALUŠIĆ, Ljerka PRESTER, and Jelena MACAN \\ Institute for Medical Research and Occupational Health, Zagreb, Croatia
}

Received in July 2008

Accepted in September 2008

\begin{abstract}
The aim of this study was to obtain preliminary exhaled breath condensate $(\mathrm{EBC}) \mathrm{pH}$ values for healthy adult Croatian subjects, and to evaluate criteria for defining respiratory health of population providing normal $\mathrm{EBC} \mathrm{pH}$ values in epidemiologic studies. In 109 adults without a history of lower airway symptoms (AS), four groups were described by narrowing the definition of "health" down to 1) without lower AS; 2) without lower and upper AS; 3 ) without AS, with normal $\mathrm{FEV}_{1}$ and bronchial normoreactivity; 4) without AS, with normal $\mathrm{FEV}_{1}$, bronchial normoreactivity, normal total IgE, and with negative skin prick test. Median EBC $\mathrm{pH}$ values did not differ between the groups $(7.72,7.73,7.73,7.73)$, but as health criteria got stricter, we observed a slight, nonsignificant increase in minimal $\mathrm{pH}$ values $(6.95,7.10,7.20,7.37)$. Median EBC pH values with interquartile range in the total sample (7.72; 7.63 to 7.76$)$ were within the range previously reported by other authors. They did not differ regarding sex, smoking habit and atopic status, and were not associated with age, $\mathrm{FEV}_{1}$ or total IgE. The non-significant trend in $\mathrm{EBC} \mathrm{pH}$ observed with stricter criteria of respiratory health and atopic status indicates the need for further research on criteria for defining healthy population in a larger sample.
\end{abstract}

KEY WORDS: atopy, bronchial reactivity, $E B C \mathrm{pH}$, health criteria, sex, skin prick test, smoking

As a completely non-invasive procedure, exhaled breath condensate $(\mathrm{EBC})$ has been extensively studied in order to explore respiratory pathophysiology and its clinical relevance in the diagnosis and treatment of a variety of respiratory diseases, including asthma, chronic obstructive pulmonary disease, allergic rhinitis, pneumonia, adult respiratory distress syndrome, lung sarcoidosis, malignant lung tumours, cystic fibrosis, idiopathic lung fibrosis, and tuberculosis (1-3).

Many different volatile and non-volatile substances have been identified in EBC, such as carbon dioxide, ammonia, hydrogen peroxide, nucleotides, isoprostanes, leukotriens, nitric oxide, peptides, cytokines, and different ions $(1,4)$. There have also been attempts of biological monitoring of occupational exposure to substances, including metals and solvents (5-7). At present, none of these potential biomarkers have been sufficiently validated for clinical use $(1,4)$, and their application in larger-scale epidemiological studies is not very practical since the majority of them can be assessed in EBC only by expensive and technically demanding methods. An exception may be $\mathrm{pH}$. It is considered to be the most validated parameter of EBC, which can be easily and reproducibly measured with non-expensive equipment (1). There are certain limitations and unresolved questions, including the source of airway acidification assessed by $\mathrm{EBC} \mathrm{pH}$, issues regarding the methodology of $\mathrm{EBC}$ collection, sample preparation and $\mathrm{EBC} \mathrm{pH}$ measurement, as well as sensitivity and specificity 
of the method (8-12). Nevertheless, a number of studies have shown that acidification caused by the inflammation of the airways, like in asthma or chronic obstructive pulmonary disease, is reflected in lower $\mathrm{EBC} \mathrm{pH}(8)$.

In order to implement this method in clinical practice and epidemiological studies, it is necessary to establish reference EBC $\mathrm{pH}$ values in a relevant population, as well as to validate the method in the laboratory. Presently, there are EBC $\mathrm{pH}$ values for more than 600 healthy adult subjects $(1,13)$. At the same time, criteria for defining "health" differ between studies, as shown in the Table 1. A great number of these subjects was selected as healthy, based on data obtained by a questionnaire alone or in combination with physical examination. In other studies, health criteria were rather strict, and included spirometry, non-specific bronchoprovocation test, and tests for objective atopy markers (total and specific serum IgE, skin prick test). This raises the question of which criteria are the most appropriate to define the health status for subjects who will provide normal, reference $\mathrm{EBC} \mathrm{pH}$ values.

In this study we introduced a method for collecting $\mathrm{EBC}$ and measuring $\mathrm{EBC} \mathrm{pH}$ in our laboratory, and we obtained preliminary $\mathrm{EBC} \mathrm{pH}$ values for healthy, adult, smoking and non-smoking Croatian population. The other aim of the study was to see how EBC $\mathrm{pH}$ values vary with different criteria for defining respiratory health and atopic status in adult population.

\section{SUBJECTS AND METHODS}

\section{Subjects and study protocol}

The study involved 157 female and 43 male office workers from Zagreb, Croatia. All were volunteers, who signed an informed consent form. The subjects completed a questionnaire and underwent the following procedures: spirometry, nonspecific bronchial challenge test, EBC collection, skin prick test with standard inhalatory allergens, and the analysis of total serum IgE level. Only the subjects who answered that they had never had lower airway symptoms ( 25 men, 84 women) were included in the study. In further analysis, the definition of "health" narrowed gradually, as described on Figure 1.

Additionally, 15 subjects (of whom five were men) reporting lower airway symptoms such as wheezing and/or dyspnoea with nonspecific bronchial hyperreactivity and positive skin prick test to common inhalatory allergens, were enrolled as positive control.

The study was designed in accordance with the Declaration of Helsinki, and was approved by the Institute's Ethics Committee.

\section{Medical history}

Using a simple questionnaire, we collected medical history data, including age, smoking habit, lower airway symptoms (including episodic dry cough not related to common cold, wheezing, chest tightness, and dyspnoea), and upper airway symptoms (including sneezing, rhinorrhoea, nasal itching, and nasal obstruction not related to common cold). Smoking was analysed as a dichotomous variable (smoker or non-smoker).

\section{Ventilatory function parameters}

Forced expiratory volume in the first second $\left(\mathrm{FEV}_{1}\right)$ was determined using the standard method (32) with spirometer Pneumoscreen II (Jaeger, Würzburg, Germany). At least three measurements were recorded per subject, and the best value was used for analysis. FEV was expressed and analysed as a percentage $\left(\mathrm{FEV}_{1} \%\right)$ of reference values (CECA II).

\section{Nonspecific Bronchial Reactivity (NBR)}

Nonspecific bronchial reactivity was assessed by means of a histamine challenge test, according to the procedure described by Chai et al. (33). The subjects inhaled doubling concentrations of histamine diphosphate solution (Sigma Chemical, St. Louis, MS) every three minutes from a DeVilbiss nebuliser (Model 646, DeVilbiss Health Care, Somerset, PA), controlled with a dosimeter (KoKo dosimeter, Ferraris Respiratory, Louisville, KY). The starting concentration of histamine diphosphate was $2 \mathrm{mg}$ $\mathrm{mL}^{-1}$, and the maximum dose used was $16 \mathrm{mg} \mathrm{mL}^{-1}$. Bronchial responsiveness was measured by recording the subjects' $\mathrm{FEV}_{1}$ on a spirometer Pneumoscreen II (Jaeger, Germany) after each inhaled dose. Bronchial hyperreactivity was established if after the inhalation of $\leq 8 \mathrm{mg} \mathrm{mL}^{-1}$ of histamine FEV dropped $\geq 20 \%$ of the value measured after the inhalation of the control solution, and further testing was stopped.

\section{Total IgE}

Total serum IgE antibodies were measured from venous blood samples using the enzyme-linked immunosorbent assay method (ELISA, IASON, Graz, 
Table 1 Orally obtained EBC pH values in healthy adults

\begin{tabular}{|c|c|c|c|}
\hline Health criteria (reference) & $\begin{array}{l}\text { Number of } \\
\text { subjects }\end{array}$ & $\begin{array}{l}\text { EBC sampling } \\
\text { device } \\
\text { (Deaeration with } \\
\text { inert gas) }\end{array}$ & pH \\
\hline healthy, no details (14) & 12 & $\mathrm{CB}($ no) & $6.15 \pm 0.16^{\mathrm{a}}$ \\
\hline healthy non-smokers, no details (15) & 30 & ES (no) & $6.30 \pm 0.30^{\mathrm{a}}$ \\
\hline $\begin{array}{l}\text { healthy non-smokers, non-atopics, without } \\
\text { respiratory symptoms, no history of lung disease; } \\
\text { normal spirometry and NBR, negative SPT (16) }\end{array}$ & 15 & $\mathrm{CB}($ no) & $6.08(5.58 \text { to } 6.64)^{b}$ \\
\hline $\begin{array}{l}\text { healthy, no details (spirometry was performed but } \\
\text { not used as an exclusion criterion) (11) }\end{array}$ & 10 & CB (no) & $7.24 \pm 0.24^{\mathrm{c}}$ \\
\hline $\begin{array}{l}\text { healthy (general health based on questionnaire) } \\
\text { (17) }\end{array}$ & 21 & RT (no) & $6.17,5.96$ to $6.31^{\mathrm{d}}$ \\
\hline \multirow{2}{*}{$\begin{array}{l}\text { healthy non-smokers, normal spirometry }\left(\mathrm{FEV}_{1}\right) \\
\text { (18) }\end{array}$} & 7 & ES (no) & $7.29 \pm 0.25^{\mathrm{a}}$ \\
\hline & 16 & ES (argon) & $8.26 \pm 0.20^{\mathrm{a}}$ \\
\hline \multirow{2}{*}{$\begin{array}{l}\text { healthy non-smokers, without acute or chronic } \\
\text { respiratory symptoms or disease, no history of } \\
\text { allergy; physical examination: NAD, normal } \\
\text { spirometry (19) }\end{array}$} & \multirow{2}{*}{48} & RT (no) & $\begin{array}{l}6.05 \pm 0.09^{\mathrm{a}}, 6.12(5.25 \text { to } 6.82)^{\mathrm{b}} \\
6.01 \pm 0.05^{\mathrm{a}}, 6.01(5.25 \text { to } 6.41)^{\mathrm{b}}\end{array}$ \\
\hline & & RT (argon) & $\begin{array}{l}7.50 \pm 0.13^{\mathrm{a}}, 7.72(5.26 \text { to } 8.13)^{\mathrm{b}} \\
7.59 \pm 0.09^{\mathrm{a}}, 7.72(6.44 \text { to } 8.12)^{\mathrm{b}}\end{array}$ \\
\hline \multirow{2}{*}{$\begin{array}{l}\text { healthy non-smokers and smokers, no history } \\
\text { of asthma, allergic rhinitis, hay fever, or atopic } \\
\text { dermatitis (20) }\end{array}$} & \multirow[b]{2}{*}{270} & RT (no) & $6.17,5.50$ to $6.78^{\mathrm{d}}$ \\
\hline & & RT (argon) & $8.09,7.41$ to $8.23^{\mathrm{d}}$ \\
\hline $\begin{array}{l}\text { subjects without respiratory symptoms and history } \\
\text { of asthma (21) }\end{array}$ & 19 & CB (argon) & $7.65 \pm 0.20^{\mathrm{e}}$ \\
\hline $\begin{array}{l}\text { healthy non-smokers, no history of allergy; normal } \\
\text { spirometry and NBR, negative SPT (22) }\end{array}$ & 10 & $\mathrm{CB}$ (argon) & $7.47 \pm 0.12,7.49 \pm 0.10^{\mathrm{a}}$ \\
\hline healthy non-smokers, no details (23) & 12 & ES (argon) & $7.46 \pm 0.48^{\mathrm{a}}$ \\
\hline $\begin{array}{l}\text { healthy non-smokers, no history of significant } \\
\text { chronic respiratory disease }(24)\end{array}$ & 76 & $\mathrm{RT}$ (argon) & $7.70 \pm 0.49^{\mathrm{a}}$ \\
\hline $\begin{array}{l}\text { subjects undergoing elective surgery, no history of } \\
\text { chronic respiratory disease }(25)\end{array}$ & 32 & $\mathrm{RT}$ (argon) & $7.90 \pm 0.23^{\mathrm{a}}$ \\
\hline healthy non-smokers, no details (25) & 10 & RT (argon) & $7.90 \pm 0.30^{\mathrm{a}}, 7.80 \pm 0.30^{\mathrm{a}}$ \\
\hline $\begin{array}{l}\text { healthy, non-smokers, without respiratory tract } \\
\text { infection within the last } 4 \text { weeks }(26)\end{array}$ & 12 & ES (argon) & $7.61(7.52 \text { to } 7.70)^{\mathrm{f}}$ \\
\hline $\begin{array}{l}\text { healthy non-smokers, without pulmonary disease, } \\
\text { non-atopics (negative SPT, not elevated total and } \\
\text { specific IgE), normal spirometry, NBR and blood } \\
\text { gas analysis (27) }\end{array}$ & 15 & ES (argon) & $7.85 \pm 0.14^{\mathrm{a}}$ \\
\hline $\begin{array}{l}\text { no history of lung disease, non-atopics (negative } \\
\text { SPT), normal spirometry and NBR (28) }\end{array}$ & 7 & ES (argon) & $7.90 \pm 0.10^{\mathrm{c}}$ \\
\hline $\begin{array}{l}\text { healthy, without respiratory disorders, any acute or } \\
\text { chronic systemic illness, and physician-diagnosed } \\
\text { gastric disease (13) }\end{array}$ & $404^{\mathrm{h}}$ & RT (argon) & $\begin{array}{l}8.00,7.80 \text { to } 8.10^{\mathrm{d}} \\
\quad(4.50 \text { to } 8.40)^{\mathrm{g}}\end{array}$ \\
\hline healthy non-smokers, without physician's diagnosis & & ES (argon) & $7.55(6.88 \text { to } 7.90)^{\mathrm{d}}$ \\
\hline $\begin{array}{l}\text { of asthma, without respiratory symptoms; normal } \\
\text { spirometry }\left(\mathrm{FEV}_{1}\right) \text {, negative bronchodilator test } \\
\text { and SPT (29) }\end{array}$ & 30 & $\mathrm{RT}$ (argon) & $7.54(7.09 \text { to } 7.93)^{\mathrm{d}}$ \\
\hline $\begin{array}{l}\text { healthy non-smokers with normal weight, without } \\
\text { heart diseases, lung diseases and allergies (medical } \\
\text { history and examination) (30) }\end{array}$ & 15 & RT (nitrogen) & $8.20 \pm 0.13^{\mathrm{a}}$ \\
\hline $\begin{array}{l}\text { healthy non-smokers, no history of respiratory } \\
\text { disease; normal spirometry, normal NBR (31) }\end{array}$ & 16 & ES (argon) & $6.72(6.38 \text { to } 6.98)^{\mathrm{d}}$ \\
\hline
\end{tabular}

${ }^{a}$ mean $\pm S D ;{ }^{b}$ median (range); ${ }^{c}$ mean $\pm S E M ;{ }^{d}$ median, interquartile range; ${ }^{e}$ geometric mean $\pm S E M ;{ }^{f}$ mean $(95 \%$ confidence interval); ${ }^{g}$ range; ${ }^{h}$ including 226 subjects older than 20 years; $E B C$ - exhaled breath condensate; $N A D$ - no abnormalities detected; NBR - non-specific bronchial reactivity; SPT-skin prick test; FEV -forced expiratory volume in the $1^{\text {st }}$ second; $C B$ - custom built EBC sampling device; ES-EcoScreen ; RT - RTube 


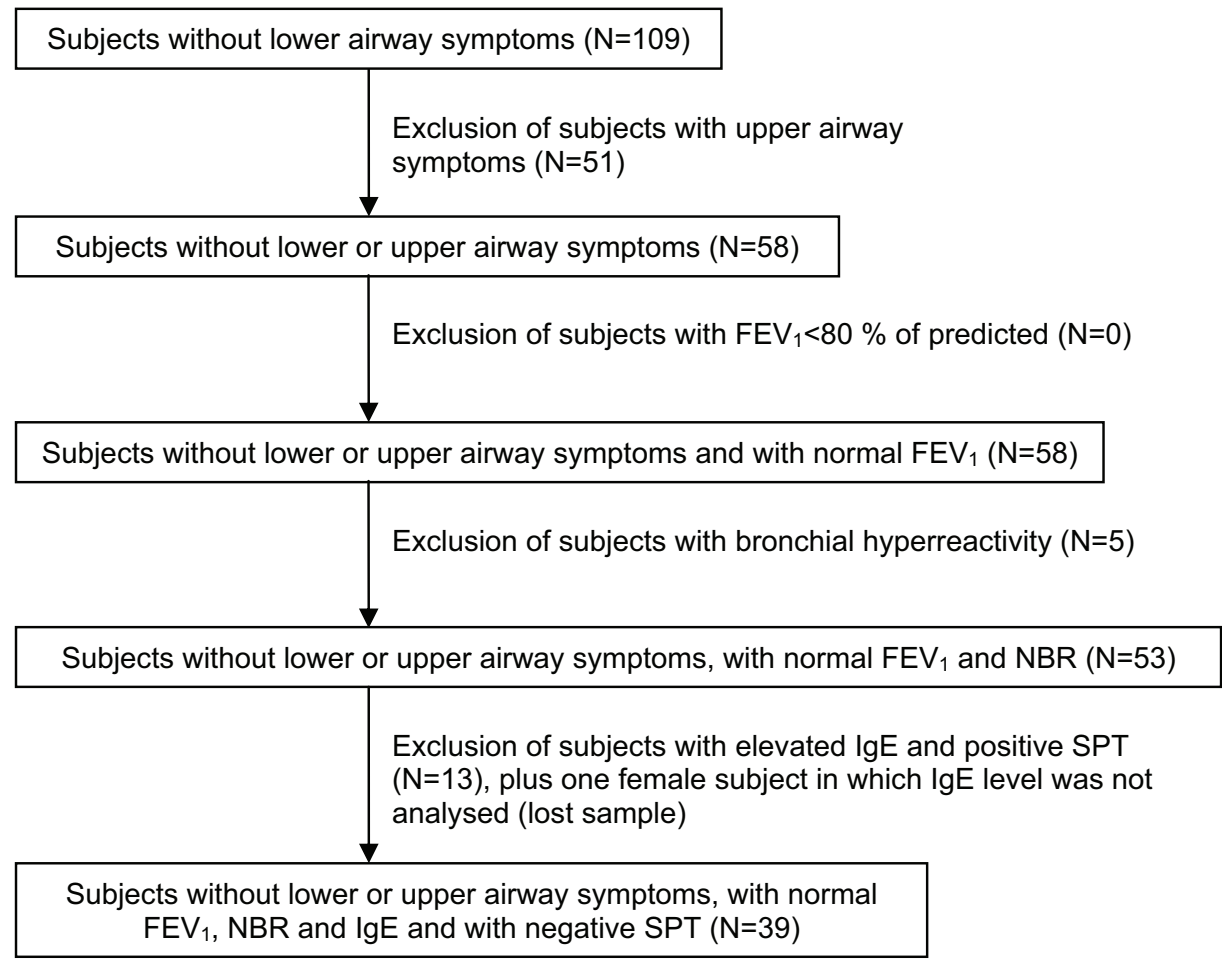

Figure 1 The steps in narrowing the definition of "health" with stricter criteria of respiratory health and atopic status $F E V_{1}$ - forced expiratory volume in the $1^{\text {st }}$ second; NBR-non-specific bronchial reactivity; SPT - skin prick test to standard inhalatory allergens

Austria) (34). IgE levels were expressed in $\mathrm{kIU} \mathrm{L}^{-1}$ and values $<150 \mathrm{kIU} \mathrm{L}^{-1}$ were considered normal.

\section{Skin prick testing}

Skin prick testing (SPT) was performed using a standard method (35) with a panel of common commercial inhalatory allergens: grass pollen mixture, birch, hazel, weed (Ambrosia elatior, Artemisia vulgaris) pollens, mites Dermatophagoides pteronyssinus, Dermatophagoides farinae, and Lepidoglyphus destructor, cat, dog, and moulds Cladosporium herbarum and Alternaria alternata (Allergopharma, Reinbeck, Germany). SPT included testing with positive control solution $\left(10 \mathrm{mg} \mathrm{mL}^{-1}\right.$ of histamine hydrochloride) and negative control solution (buffer solution). Skin reaction (wheal) was evaluated after 15 min. The mean skin reaction (mean wheal diameter) was calculated according to the formula $(\mathrm{D}+\mathrm{d}) / 2$, where $\mathrm{D}$ represents the largest longitudinal diameter and $d$ its midpoint orthogonal diameter in millimetres. For statistical evaluation, the difference between mean skin reaction to each allergen and negative control solution was used as a parameter of SPT reactivity. The results of SPT were considered positive (positive SPT) when the mean wheal diameter was larger than the negative control for more than $3 \mathrm{~mm}$ to at least one tested allergen.

Atopy status was defined as the presence of both elevated total $\operatorname{IgE}$ and positive SPT to at least one tested allergen.

\section{$E B C$ collection and $\mathrm{pH}$ measurement}

All subjects were asked to fast for at least $12 \mathrm{~h}$ and refrain from smoking at least one hour before sampling. For the sampling, all subjects wore nose clips. Each subject provided a single EBC sample, breathing tidally into a commercial condenser (Eco Screen; Jaeger, Germany) for $15 \mathrm{~min}$ through a mouthpiece and a two-way non-rebreathing valve that also prevented saliva contamination due to integrated saliva trap. The condensate was collected into a Teflon-coated tube, which was disinfected and rinsed with tap water and wiped before sampling. After collection, the samples were frozen at $-20^{\circ} \mathrm{C}$ until analysis.

The samples were allowed to thaw to room temperature and were left exposed to ambient air until $\mathrm{pH}$ was stable (for three hours on average). $\mathrm{pH}$ was 
measured using a Mettler $\mathrm{pH}$ meter (standard glass electrode-MP 220 Toledo, accuracy $\pm 0,01$ ) that had been calibrated with standard buffers (Mettler Toledo) at two points ( $\mathrm{pH} 7.00$ and $\mathrm{pH} 4.01$ ).

\section{Statistical analysis}

The results are presented as mean values with standard deviations (age, $\mathrm{FEV}_{1}$ ) or as medians with range (smoking index, total $\operatorname{IgE}, \mathrm{EBC} \mathrm{pH}$ ) and interquartile range $(\mathrm{EBC} \mathrm{pH})$. Differences between groups (e.g. men and women, smokers and nonsmokers, subject with and without upper airway symptoms) were tested with Student's $t$-test (age, $\mathrm{FEV}_{1}$ ), Mann-Whitney $\mathrm{U}$ test (smoking index, $\mathrm{EBC} \mathrm{pH}$, total $\mathrm{IgE}$ ), or Fisher's exact test (number of smokers, prevalence of respiratory symptoms, bronchial hyperreactivity, elevated $\operatorname{IgE}$ and positive SPT). Possible associations between EBC $\mathrm{pH}$ and age and $\mathrm{FEV}_{1}$ and total $\mathrm{IgE}$ were analysed with Spearman's correlation. Difference in EBC pH was tested between four overlapping groups defined as healthy according to criteria shown in Figure 1. The healthy groups were analysed as independent samples using the Kruskal-Wallis analysis of variance. EBC $\mathrm{pH}$ of each healthy group was also compared with positive control group using the Mann-Whitney U test. A P value of less than 0.05 was considered statistically significant in all analyses. Statistical analysis was performed using statistical software Stata/SE 10.0 for Windows (StatCorp LP, TX, USA).

\section{RESULTS AND DISCUSSION}

Table 2 shows the data about the age, smoking, respiratory parameters, and the prevalence of upper airway symptoms and positive objective atopy markers in subjects without a history of lower airway symptoms. The only difference found between men and women was a significantly higher prevalence of positive SPT and positive both objective atopy markers in men. The prevalence of positive SPT was more than two times higher, and the prevalence of positive both atopy markers seven times higher in men than in women. Only one female subject had $\mathrm{FEV}_{1}$ lower than $80 \%$ of the predicted value. Her FEV ${ }_{1}$ was $78.5 \%$, and $\mathrm{EBC} \mathrm{pH} 7.78$.

Table 3 shows the profile of positive control subjects. Male to female ratio (approximately 1:3; Pearson $\chi^{2}=0.78, \mathrm{P}=0.355$ ), the number of smokers (Pearson $\left.\chi^{2}=0.79, \mathrm{P}=0.550\right)$, as well as age $(\mathrm{t}=1.502$, $\mathrm{P}=0.136$ ), did not differ significantly between subjects without lower airway symptoms and positive controls. Due to a very low number of smokers (three subjects) in the positive control group, smoking was not further analysed as a variable in this group. As expected, $\mathrm{FEV}$, was lower in positive controls $(\mathrm{t}=-2.4673, \mathrm{P}=0.015)$ and $\operatorname{IgE}$ levels were higher $(\mathrm{z}=4.082, \mathrm{P}<0.0001)$ than in subjects without lower airway symptoms. In addition, the prevalence of upper airway symptoms was significantly higher in positive controls (14 out

Table 2 General, respiratory, and atopic parameters in subjects without lower airway symptoms

\begin{tabular}{|c|c|c|c|c|c|c|c|c|c|c|}
\hline \multirow[b]{2}{*}{$\begin{array}{l}\text { Subject } \\
\text { (N) }\end{array}$} & \multirow[b]{2}{*}{$\begin{array}{c}\begin{array}{c}\text { Age / } \\
\text { years }\end{array} \\
\text { Mean } \pm \\
\text { SD }\end{array}$} & \multicolumn{2}{|c|}{ Smoking status } & \multirow[b]{2}{*}{$\begin{array}{c}\begin{array}{c}\text { Upper } \\
\text { airway } \\
\text { symptoms }\end{array} \\
\mathrm{N}(\%)\end{array}$} & \multirow[b]{2}{*}{$\begin{array}{c}\text { FEV }_{1} / \\
\% \text { of } \\
\text { expected } \\
\text { value } \\
\text { Mean } \pm \text { SD }\end{array}$} & \multirow[b]{2}{*}{$\begin{array}{l}\text { Bronchial } \\
\text { hyperre- } \\
\frac{\text { activity }^{\mathrm{a}}}{\mathrm{N}(\%)}\end{array}$} & \multicolumn{2}{|c|}{ Total IgE } & \multirow[b]{2}{*}{$\begin{array}{l}\text { Positive } \\
\text { SPT } \\
\text { N (\%) }\end{array}$} & \multirow[b]{2}{*}{$\begin{array}{c}\text { Elevated } \\
\text { IgE and } \\
\text { positive } \\
\text { SPT } \\
N(\%)\end{array}$} \\
\hline & & $\frac{\text { Smokers }}{\mathrm{N}(\%)}$ & $\begin{array}{c}\begin{array}{c}\text { Smoking } \\
\text { index in } \\
\text { smokers }\end{array} \\
\text { median, range }\end{array}$ & & & & ${\underline{\mathrm{kIU} \mathrm{L}^{-1}}}^{-1}$ & $\frac{\text { Elevated }}{\mathrm{N}(\%)}$ & & \\
\hline & $2.2 \pm 9.0$ & 34( & & & $105.5 \pm 11.8$ & & $24.3,0$ & & & \\
\hline & $4 \pm 9.2$ & $5(20.0)$ & 600 & & $106.3 \pm 11.6$ & & $40.5,0$ & & & \\
\hline & $.8 \pm 8.9$ & $29(34.5)$ & & & $105.2 \pm 11.9^{c}$ & & $21.8,0$ to & & & \\
\hline $\begin{array}{l}\text { ference } \\
\boldsymbol{v} \boldsymbol{s}\end{array}$ & $\begin{array}{l}\mathrm{t}=0.7655 \\
\mathrm{P}=0.446\end{array}$ & $\begin{array}{l}\chi^{2}=1.894 \\
\mathrm{P}=0.222\end{array}$ & & $\begin{array}{l}\chi^{2}=1.517 \\
P=0.258\end{array}$ & $\begin{array}{l}\mathrm{t}=0.389 \\
\mathrm{P}=0.698\end{array}$ & $\begin{array}{l}\chi^{2}=2.023 \\
P=0.292\end{array}$ & $\begin{array}{l}\mathrm{z}=1.501 \\
\mathrm{P}=0.133\end{array}$ & $\begin{array}{l}\chi^{2}=4.481 \\
\mathrm{P}=0.052\end{array}$ & $\begin{aligned} \chi^{2} & =8.019 \\
\mathrm{P} & =0.011\end{aligned}$ & $\begin{array}{r}\chi^{2}=13.598 \\
\mathrm{P}=0.000\end{array}$ \\
\hline
\end{tabular}

${ }^{a}$ In 2 women NBR test was not performed due to contraindications; ${ }^{b}$ Serum sample from one subject was lost; ${ }^{c}$ One woman had FEV below $80 \%$ (78.5\%); EBC - exhaled breath condensate; FEV - forced expiratory volume in the $1^{\text {st }}$ second; NBR - non-specific bronchial reactivity; SPT - skin prick test to standard inhalatory allergens; Differences between men and women were tested by Student's t-test (age, FEV1), Mann-Whitney U test (smoking index, total IgE), or by Fisher's exact test (number of smokers, upper airway symptoms, bronchial hyperreactivity, elevated IgE, positive SPT, and elevated IgE + positive SPT). A P value of less than 0.05 was considered statistically significant. 
of 15 subjects; Pearson $\chi^{2}=11.45$, Fisher's exact $\mathrm{P}=0.001$ ).

Table 4 shows median EBC $\mathrm{pH}$ values with interquartile range and minimum and maximum values for subjects without lower airway symptoms. They are within the range of values previously reported by other authors (Table 1). Table 4 also gives the values for positive controls.

In subjects without lower airway symptoms EBC $\mathrm{pH}$ was not associated with age (Spearman's $\mathrm{r}=0.049, \mathrm{P}=0.611), \mathrm{FEV}_{1}(\mathrm{r}=0.024, \mathrm{P}=0.806)$, or $\mathrm{IgE}$ $(\mathrm{r}=-0.148, \mathrm{P}=0.126)$. There were no differences in EBC $\mathrm{pH}$ between men (median, 7.73, interquartile range, 7.63 to 7.77$)$ and women $(7.71,7.64$ to 7.76 ; $\mathrm{z}=0.126 ; \mathrm{P}=0.900)$, smokers $(7.69,7.48$ to 7.77$)$ and non-smokers $(7.73,7.65$ to $7.75 ; \mathrm{z}=0.809 ; \mathrm{P}=0.419)$, subject without upper airway symptoms $(7.73,7.66$ to 7.76) and subjects with upper airway symptoms (7.70, 7.53 to $7.76 ; z=1.307, \mathrm{P}=0.191)$, subjects with bronchial normoreactivity $(7.72,7.63$ to 7.76$)$ and those with bronchial hyperreactivity $(7.69,7.64$ to 7.75; $\mathrm{z}=0.377, \mathrm{P}=0.706)$, and between atopics $(7.76$, 7.63 to 7.87$)$ and non-atopics $(7.71,7.63$ to 7.76 ; $\mathrm{z}=-1.221 ; \mathrm{P}=0.222)$. The correlations between $\mathrm{EBC}$ $\mathrm{pH}$ and age and $\mathrm{FEV}_{1}$, and $\mathrm{IgE}$ were not significant in positive controls as well $(\mathrm{r}=-0.1530, \mathrm{P}=0.586$; $\mathrm{r}=0.2484, \mathrm{P}=0.372 ; \mathrm{r}=-0.3753, \mathrm{P}=0.168$, respectively). Just like subjects without lower airway symptoms, positive control men and women did not differ in $\mathrm{EBC} \mathrm{pH}(\mathrm{z}=-0.919, \mathrm{P}=0.358)$. It has repeatedly been shown by other authors that age, sex, and smoking have no effect on $\mathrm{EBC} \mathrm{pH}(13,17,19,20,24)$. On the other hand, there are studies showing acute effects of smoking on certain EBC parameters, such as 8isoprostane, $\mathrm{H}_{2} \mathrm{O}_{2}$, leukotriene $\mathrm{B}_{4}$ and interleukin-6 levels (36-39), and $\mathrm{EBC} \mathrm{pH}(40)$. The intensity of current smoking (number of cigarette packs smoked per day now) negatively correlated with $\mathrm{EBC} \mathrm{pH}$ (40). However, it seems that active smoking does not affect $\mathrm{EBC} \mathrm{pH}$ in subjects without a respiratory disease who refrain from smoking at least one hour before EBC collection $(17,24)$. The situation could be different in asthma patients, in whom smoking is associated with lower EBC pH than in non-smoking asthmatics (41). In our subjects with lower airway symptoms (positive control), however, the number of smokers was too low to allow statistical analysis, as mentioned above. To avoid possible acute effect of smoking on $\mathrm{EBC} \mathrm{pH}$, all subjects that entered the study did not smoke for at least one hour before EBC sampling.

EBC is believed to contain droplets of fluid lining the pulmonary surfaces (epithelial lining fluid), but their source may just as well be the upper respiratory tract and the upper gastrointestinal tract (42). In light of the concept of "united airways", it is also possible that upper and lower airway disorders co-exist, and that the progression of atopic disease that manifests itself as allergic rhinitis can lead to acidification of the lower airways before asthma symptoms appear (43). This is supported by the findings that children with allergic rhinitis have lower $\mathrm{EBC} \mathrm{pH}$ than healthy children, even in the absence of clinical signs of inflammation in the lower airways $(43,44) \mathrm{EBC} p H$ in non-allergic upper respiratory disorders has not been studied so far. We did not observe an effect of the presence of upper airway symptoms on $\mathrm{EBC} \mathrm{pH}$ in adult subjects without lower airway symptoms. Since these subjects were mainly non-atopics (99 out of 109), we could not establish a difference between the effects of atopic and non-atopic upper airway symptoms on $\mathrm{EBC} \mathrm{pH}$.

The lack of association between $\mathrm{FEV}_{1}$ or nonspecific bronchial reactivity and $\mathrm{EBC} \mathrm{pH}$ in our study is no surprise as it enrolled only healthy subjects. A correlation between $\mathrm{EBC} \mathrm{pH}$ and $\mathrm{FEV}_{1}$ was observed in children with asthma (43) and in adult patients with asthma, chronic obstructive pulmonary disease (COPD), or bronchiectasis, but not in healthy control subjects (non-atopics with normal lung function and normal bronchial reactivity) (22). Data on $\mathrm{EBC} \mathrm{pH}$ and non-specific bronchial reactivity are scarce. A positive trend (although not statistically significant) was found between $\mathrm{EBC} \mathrm{pH}$ and non-specific bronchial reactivity in children with wheezing (45), but data for a population without airway symptoms are not available in literature.

As pointed out by Paget-Brown et al. (13) and Koutsokera et al. (1), there are plenty of studies of $\mathrm{EBC} \mathrm{pH}$ which include healthy subjects, primarily to compare them with subjects with respiratory disease. Table 1 summarises the $\mathrm{pH}$ values of orally obtained EBC samples in healthy adults from different published studies. Between these studies, "health" criteria differ a lot. Differences are also substantial in the use of EBC sampling device, sampling procedure (e.g. duration), storage of samples (e.g. temperature and duration), sample preparation (native or treated with inert gas), and $\mathrm{pH}$ measurement (standard $\mathrm{pH}$ electrode, microelectrode, blood gas analyzer). An extensive study by Paget-Brown et al. (13), for example, included 404 healthy subjects of both sexes, with 226 subjects older than 20 years. The 
Table 3 General, respiratory, and atopic parameters in positive controls*

\begin{tabular}{|c|c|c|c|c|c|c|c|}
\hline \multirow[b]{2}{*}{ Subjects (N) } & \multirow[b]{2}{*}{$\frac{\text { Age / year }}{\text { Mean } \pm \text { SD }}$} & \multicolumn{2}{|c|}{ Smoking status } & \multirow[b]{2}{*}{$\begin{array}{l}\text { Upper airway } \\
\frac{\text { symptoms }}{\mathrm{N}(\%)}\end{array}$} & \multirow{2}{*}{$\begin{array}{c}\text { FEV }{ }_{1} / \\
\% \text { of expected } \\
\underline{\text { value }} \\
\text { Mean } \pm \text { SD }\end{array}$} & \multicolumn{2}{|c|}{ Total IgE } \\
\hline & & $\frac{\text { Smokers }}{\mathrm{N}(\%)}$ & $\begin{array}{l}\text { Smoking index } \\
\text { in smokers } \\
\text { Median, range }\end{array}$ & & & $\frac{\underline{k I U ~ L}^{-1}}{\text { Median, range }}$ & $\frac{\text { Elevated }}{\mathrm{N}(\%)}$ \\
\hline Total (15) & $46.0 \pm 10.9$ & $3(20.0)$ & 75,35 to 240 & $14(93.3)$ & $96.8 \pm 18.8$ & $180.6,15.5$ to 795.2 & $9(60.0)$ \\
\hline $\operatorname{Men}(5)$ & $46.6 \pm 15.3$ & $1(20.0)$ & 35 & $5(100.0)$ & $89.8 \pm 21.8$ & $333.2,180.6$ to 795.2 & $5(100.0)$ \\
\hline Women (10) & $45.7 \pm 8.9$ & $2(20.0)$ & 158,75 to 240 & $9(90.0)$ & $100.3 \pm 17.4$ & $74.4,15.5$ to 418.5 & $4(40.0)$ \\
\hline
\end{tabular}

*Positive controls were subjects with lower airway symptoms, bronchial hyperreactivity, and positive skin prick test to common inhalatory allergens

$E B C$ - exhaled breath condensate; $F E V_{1}$-forced expiratory volume in the $1^{\text {st }}$ second

Table 4 EBC pH in subjects with different criteria for respiratory health and atopy, and in positive controls

\begin{tabular}{lcccccc}
\hline Subjects & $\mathbf{N}$ & Mean \pm SD & Median & Range & $\begin{array}{c}\text { Interquartile } \\
\text { range / } \\
\mathbf{P}_{\mathbf{2 5}}-\mathbf{P}_{75}\end{array}$ & $\begin{array}{c}\text { Comparison with positive } \\
\text { control }\end{array}$ \\
\cline { 3 - 6 } & & & & & & \\
Without lower airway symptoms & & & & \\
Men & 25 & $7.67 \pm 0.22$ & 7.73 & 7.20 to 8.26 & to 7.77 & \\
Women & 84 & $7.67 \pm 0.20$ & 7.71 & 6.95 to 8.10 & 7.64 to 7.76 & \\
Total & 109 & $7.67 \pm 0.21$ & 7.72 & 6.95 to 8.26 & 7.63 to 7.76 & $\mathrm{z}=-2.343, \mathrm{P}=0.0191$
\end{tabular}

Without lower and upper airway symptoms

$\begin{array}{lllllll}\text { Men } & 16 & 7.71 \pm 0.15 & 7.75 & 7.20 \text { to } 7.87 & 7.68 \text { to } 7.77 & \\ \text { Women } & 42 & 7.68 \pm 0.17 & 7.73 & 7.10 \text { to } 7.96 & 7.66 \text { to } 7.75 & \\ \text { Total } & 58 & 7.69 \pm 0.16 & 7.73 & 7.10 \text { to } 7.96 & 7.66 \text { to } 7.76 & \mathrm{Z}=-2.756, \mathrm{P}=0.0059\end{array}$

Without airway symptoms, with normal FEV 1 and NBR

$\begin{array}{lllllll}\text { Men } & 15 & 7.71 \pm 0.15 & 7.75 & 7.20 \text { to } 7.87 & 7.66 \text { to } 7.77 & \\ \text { Women } & 38 & 7.69 \pm 0.14 & 7.73 & 7.32 \text { to } 7.96 & 7.66 \text { to } 7.75 & \\ \text { Total } & 53 & 7.69 \pm 0.14 & 7.73 & 7.20 \text { to } 7.96 & 7.66 \text { to } 7.76 & \mathrm{Z}=-2.785, \mathrm{P}=0.0054\end{array}$

Without airway symptoms, with normal $\mathrm{FEV}_{1}$, NBR and total IgE, and with negative SPT

$\begin{array}{lcccccc}\text { Men } & 7 & 7.71 \pm 0.06 & 7.70 & 7.64 \text { to } 7.78 & 7.66 \text { to } 7.77 & \\ \text { Women } & 32 & 7.70 \pm 0.14 & 7.73 & 7.37 \text { to } 7.96 & 7.67 \text { to } 7.77 & \\ \text { Total } & 39 & 7.70 \pm 0.13 & 7.73 & 7.37 \text { to } 7.96 & 7.66 \text { to } 7.77 & \mathrm{z}=-2.771, \mathrm{P}=0.0056\end{array}$

\begin{tabular}{lccccc}
\hline $\begin{array}{l}\text { Positive } \\
\text { controls }\end{array}$ & & & & & \\
Men & 5 & $7.59 \pm 0.37$ & 7.45 & 7.30 to 8.22 & 7.39 to 7.60 \\
Women & 10 & $7.59 \pm 0.14$ & 7.60 & 7.30 to 7.76 & 7.50 to 7.73 \\
Total & 15 & $7.59 \pm 0.23$ & 7.56 & 7.30 to 8.22 & 7.45 to 7.73
\end{tabular}

$E B C$-exhaled breath condensate; $P_{25}-25^{\text {th }}$ percentile; $P_{75}-75^{\text {th }}$ percentile; FEV - forced expiratory volume in the $1^{\text {st }}$ second; NBR - non-specific bronchial reactivity; SPT - skin prick test to standard inhalatory allergens; Positive control - subjects reporting wheezing and/or dyspnoea with positive SPT and bronchial hyperreactivity Median EBC $p H$ values did not differ between the healthy groups (Kruskal-Wallis analysis of variance, $P=0.817)$. The difference between healthy groups and positive control was tested by Mann-Whitney U test. 


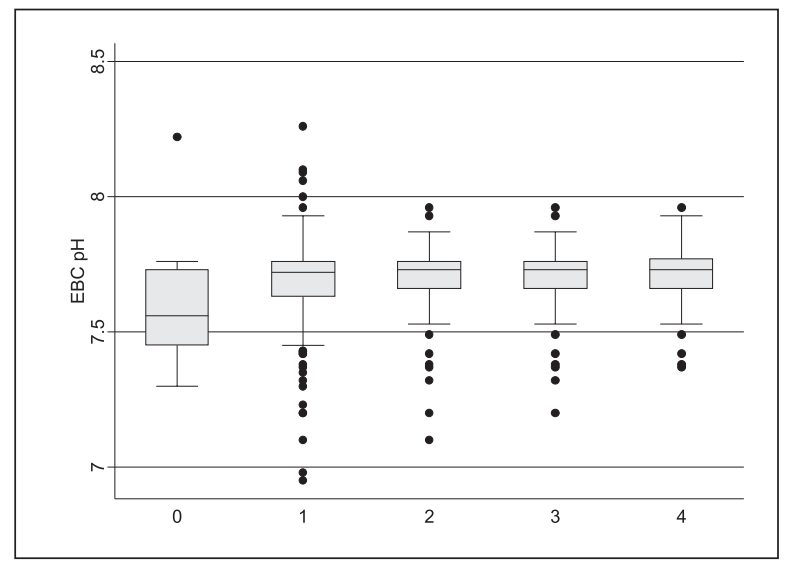

Figure 2 Box plots of $E B C$ pH distribution in the four health categories and in positive control

0 - Positive control (subjects reporting wheezing and/or dyspnoea with positive SPT and bronchial hyperreactivity; $N=15) ; 1$ - Subjects without lower airway symptoms $(N=109)$; 2 - Subjects without lower and upper airway symptoms $(N=58) ; 3$ - Subjects without airway symptoms, with normal $F E V$ and NBR (N=53); 4-Subjects without airway symptoms, with normal $F E V_{1}, N B R$ and total $\operatorname{IgE}$, and with negative SPT $(N=39) ; E B C$ - exhaled breath condensate; $F E V_{1}$ - forced expiratory volume in the $1^{\text {st }}$ second; NBR-non-specific bronchial reactivity; SPT - skin prick test to standard inhalatory allergens

Data are presented as medians with interquartile ranges, adjacent values, and minimal and maximal values.

health status was self-described by volunteers, and certain exclusion criteria were introduced to refine the selection. Excluded were smoking subjects, as well as those who reported chronic upper or lower airway symptoms, or symptoms related to viral respiratory tract infection (common cold). Similarly, the study of Vaughan et al. (24) on factors relevant to EBC $\mathrm{pH}$ monitoring involved 76 healthy non-smoking subjects whose respiratory health was defined as the absence of a "history of significant chronic respiratory disease". The most recent study by Hauswirth et al. (20) included 270 healthy subjects of African ancestry whose health status was based on self-reported absence of a history of asthma, allergic rhinitis, hay fever, or atopic dermatitis. Studies in which respiratory and/or atopic status was more extensively evaluated usually involved a small number of subjects who served as a controls $(16,22,27-29,31)$. Which are the most appropriate health criteria for the selection of reliable and representative healthy control providing normal EBC $\mathrm{pH}$ values is still an unresolved issue that may be of particular interest for epidemiologic research. We defined our healthy subjects according to different criteria based on subjective and objective respiratory and atopic parameters. Four overlapping groups were described by narrowing the definition of "health" in four steps: in the $1^{\text {st }}$ step we excluded subjects with lower airway symptoms (also the criteria for enrolment in the study); in the $2^{\text {nd }}$, from the group formed in the $1^{\text {st }}$ step we excluded subjects with upper airway symptoms; in the $3^{\text {rd }}$, from the group formed in the $2^{\text {nd }}$ step we excluded subjects with bronchial hyperreactivity and $\mathrm{FEV}_{1}<80 \%$, and in the $4^{\text {th }}$ step, from the group formed in previous step we excluded atopic subjects (with elevated $\operatorname{IgE}$ and positive SPT) (Figure 1, Table 4). Median values (7.72, 7.73, 7.73, and 7.73 for each respective step) and interquartile ranges were quite similar between the groups, and they showed no difference in $\mathrm{EBC} \mathrm{pH}$ (Kruskal-Wallis ANOVA: $\chi^{2}=0.934, \mathrm{P}=0.817$ ). However, the range of values narrowed with stricter criteria, and we observed a slight increase in minimal $(6.95,7.10,7.20$, and 7.37, respectively) and mean $\mathrm{pH}$ values $(7.67,7.69$, 7.69 , and 7.70, respectively) (Figure 2). This, albeit non-significant, trend indicates the need for further research on a larger sample. Since our sample size was limited, especially regarding healthy groups meeting stricter health criteria, any firm conclusion would be premature.

The $\mathrm{pH}$ values obtained from our participants are closer to values measured in samples after deaeration/ decarbonation, although we did not treat the samples with inert gas (argon or nitrogen) to stabilise the $\mathrm{pH}$. In general, literature describes three main approaches to $\mathrm{EBC} \mathrm{pH}$ measurement: 1) in native samples, fresh or after defrosting; 2) after treating the samples with inert gas (bubbling or overlaying); and 3) at a standard $\mathrm{CO}_{2}$ level of the sample (1). The last method is proposed to be the most accurate (10). In our study, the samples were left at room temperature to permit gas exchange (primarily $\mathrm{CO}_{2}$ as a major $\mathrm{EBC}$ volatile component) with ambient air. We are aware that this procedure probably eliminates less $\mathrm{CO}_{2}$ from the sample then does deaeration/decarbonation with inert gas. Also, a greater variation in $\mathrm{CO}_{2}$ content (and consequently in $\mathrm{pH}$ value) is to be expected in our samples compared to dearated/decarbonated samples, and especially to samples in which $\mathrm{pH}$ was measured at a standard $\mathrm{CO}_{2}$ level of the sample. Since our method has not yet been validated, in order to see whether it could discriminate between subjects with and without inflammatory changes in the airways, we introduced a positive control, i.e. subjects reporting lower airway symptoms typical for asthma (wheezing and/or dyspnoea) with positive SPT and bronchial hyperreactivity. We found that each healthy group had a significantly ( 0.16 to 
0.17 units) higher EBC $\mathrm{pH}$ than positive control, indicating that the described method is able to detect airway acidification.

\section{CONCLUSION}

This study brings the first results on EBC $\mathrm{pH}$ in adult Croatian population without respiratory disorders. EBC $\mathrm{pH}$ values seem not to be affected by age, sex, smoking, upper airway symptoms, nonspecific bronchial reactivity, or atopy. The established normal $\mathrm{EBC} \mathrm{pH}$ range in our study is mildly alkaline and tight, and is comparable with data published in literature. Our data do not suggest that stricter health criteria for defining normal population bring an advantage for epidemiologic studies of $\mathrm{EBC} \mathrm{pH}$. Exclusion of subjects with respiratory symptoms and atopy did however show a slight trend toward more alkaline $\mathrm{pH}$. This calls for further research in a larger number of subjects.

\section{Acknowledgement}

This work was supported by the Institute for Medical Research and Occupational Health, Zagreb (grant no. 655 "Immunotoxic effects of the indoor bioaerosols and life-style") and by the Ministry of Science, Education and Sports, Republic of Croatia.

\section{REFERENCES}

1. Koutsokera A, Loukides S, Gourgoulianis KI, Kostikas K. Biomarkers in the exhaled breath condensate of healthy adults: mapping the path towards reference values. Curr Med Chem 2008;15:620-30

2. Carpagnano GE, Foschino-Barbaro MP, Resta O, Gramiccioni E, Carpagnano F. Endothelin-1 is increased in the breath condensate of patients with non-small-cell lung cancer. Oncology 2004;66:180-4.

3. Gessner C, Kuhn H, Toepfer K, Hammerschmidt S, Schauer $\mathrm{J}$, Wirtz H. Detection of $\mathrm{p} 53$ gene mutations in exhaled breath condensate of non-small cell lung cancer patients. Lung Cancer 2004;43:215-22.

4. Horvath I, Hunt J, Barnes PJ, Alving K, Antczak A, Baraldi E, Becher G, van Beurden WJ, Corradi M, Dekhuijzen R, Dweik RA, Dwyer T, Effros R, Erzurum S, Gaston B, Gessner C, Greening A, Ho LP, Hohlfeld J, Jobsis Q, Laskowski D, Loukides S, Marlin D, Montuschi P, Olin AC, Redington AE, Reinhold P, van Rensen EL, Rubinstein I, Silkoff P, Toren K, Vass G, Vogelberg C, Wirtz H. ATS/ERS Task force on exhaled breath condensate. Exhaled breath condensate: methodological recommendations and unresolved questions. Eur Respir J 2005;26:523-48.

5. Mutti A, Corradi M. Recent developments in human biomonitoring: non-invasive assessment of target tissue dose and effects of pneumotoxic metals. Med Lav 2006;97:199206.

6. Goldoni M, Catalani S, De Palma G, Manini P, Acampa O, Corradi M, Bergonzi R, Apostoli P, Mutti A. Exhaled breath condensate as a suitable matrix to assess lung dose and effects in workers exposed to cobalt and tungsten. Environ Health Perspect 2004;112:1293-8.

7. Maniscalco M, De Laurentiis G, Pentella C, Mormile M, Sanduzzi A, Carratu P, Sofia M. Exhaled breath condensate as matrix for toluene detection: A preliminary study. Biomarkers 2006;11:233-40.

8. Hunt J. Exhaled breath condensate $\mathrm{pH}$ assays. Immunol Allergy Clin North Am 2007;27:597-606.

9. Prieto L, Ferrer A, Palop J, Domenech J, Llusar R, Rojas R. Differences in exhaled breath condensate $\mathrm{pH}$ measurements between samples obtained with two commercial devices. Respir Med 2007;101:1715-20.

10. Kullmann T, Barta I, Lazar Z, Szili B, Barat E, Valyon M, Kollai M, Horvath I. Exhaled breath condensate $\mathrm{pH}$ standardised for $\mathrm{CO}_{2}$ partial pressure. Eur Respir $\mathrm{J}$ 2007;29:496-501.

11. Effros RM, Casaburi R, Su J, Dunning M, Torday J, Biller J, Shaker R. The effects of volatile salivary acids and bases on exhaled breath condensate $\mathrm{pH}$. Am J Respir Crit Care Med 2006; 173:386-92.

12. Leung TF, Li CY, Yung E, Liu EK, Lam CW, Wong GW. Clinical and technical factors affecting $\mathrm{pH}$ and other biomarkers in exhaled breath condensate. Pediatr Pulmonol 2006:41:87-94.

13. Paget-Brown AO, Ngamtrakulpanit L, Smith A, Bunyan D, Hom S, Nguyen A, Hunt JF. Normative data for $\mathrm{pH}$ of exhaled breath condensate. Chest 2006;129:426-30.

14. Tate S, MacGregor G, Davis M, Innes JA, Greening AP. Airways in cystic fibrosis are acidified: detection by exhaled breath condensate. Thorax 2002;57:926-9.

15. McCafferty JB, Bradshaw TA, Tate S, Greening AP, Innes JA. Effects of breathing pattern and inspired air conditions on breath condensate volume, $\mathrm{pH}$, nitrite, and protein concentrations. Thorax 2004;59:694-8.

16. Ojoo JC, Mulrennan SA, Kastelik JA, Morice AH, Redington $\mathrm{AE}$. Exhaled breath condensate $\mathrm{pH}$ and exhaled nitric oxide in allergic asthma and in cystic fibrosis. Thorax 2005;60:22-6.

17. Bloemen K, Lissens G, Desager K, Schoeters G. Determinants of variability of protein content, volume and $\mathrm{pH}$ of exhaled breath condensate. Respir Med 2007;101:1331-7.

18. Niimi A, Nguyen LT, Usmani O, Mann B, Chung KF. Reduced $\mathrm{pH}$ and chloride levels in exhaled breath condensate of patients with chronic cough. Thorax 2004;59:608-12.

19. Brooks SM, Haight RR, Gordon RL. Age does not affect airway $\mathrm{pH}$ and ammonia as determined by exhaled breath measurements. Lung 2006;184:195-200.

20. Hauswirth DW, Sundy JS, Mervin-Blake S, Fernandez CA, Patch KB, Alexander KM, Allgood S, McNair PD, Levesque $\mathrm{MC}$. Normative values for exhaled breath condensate $\mathrm{pH}$ and its relationship to exhaled nitric oxide in healthy African Americans. J Allergy Clin Immunol 2008;122:101-6.

21. Hunt JF, Fang KZ, Malik R, Snyder A, Malhotra N, PlattsMills TAE. Gaston B. Endogenous airway acidification - Implications for asthma pathophysiology. Am J Respir Crit Care Med 2000;161:694-9.

22. Kostikas K, Papatheodorou G, Ganas K, Psathakis K, Panagou P, Loukides S. pH in expired breath condensate of 
patients with inflammatory airway diseases. Am J Respir Crit Care Med 2002;165:1364-70.

23. Gessner C, Hammerschmidt S, Kuhn H, Seyfarth HJ, Sack U, Engelmann L, Schauer J, Wirtz H. Exhaled breath condensate acidification in acute lung injury. Respir Med 2003;97:118894.

24. Vaughan J, Ngamtrakulpanit L, Pajewski TN, Turner R, Nguyen TA, Smith A, Urban P, Hom S, Gaston B, Hunt J. Exhaled breath condensate $\mathrm{pH}$ is a robust and reproducible assay of airway acidity. Eur Respir J 2003;22:889-94.

25. Wells K, Vaughan J, Pajewski TN, Hom S, Ngamtrakulpanit L, Smith A, Nguyen A, Turner R, Hunt J. Exhaled breath condensate $\mathrm{pH}$ assays are not influenced by oral ammonia. Thorax 2005;60:27-31.

26. Borrill Z, Starkey C, Vestbo J, Singh D. Reproducibility of exhaled breath condensate $\mathrm{pH}$ in chronic obstructive pulmonary disease. Eur Respir J 2005;25:269-74.

27. Carpagnano GE, Foschino Barbaro MP, Cagnazzo M, Di Gioia G, Giliberti T, Di Matteo C, Resta O. Use of exhaled breath condensate in the study of airway inflammation after hypertonic saline solution challenge. Chest 2005;128:315966.

28. Carpagnano GE, Foschino Barbaro MP, Resta O, Gramiccioni E, Valerio NV, Bracciale P, Valerio G. Exhaled markers in the monitoring of airways inflammation and its response to steroid's treatment in mild persistent asthma. Eur J Pharmacol 2005;519:175-81.

29. Soyer OU, Dizdar EA, Keskin O, Lilly C, Kalayci O. Comparison of two methods for exhaled breath condensate collection. Allergy 2006;61:1016-8.

30. Riediker M, Danuser B. Exhaled breath condensate $\mathrm{pH}$ is increased after moderate exercise. J Aerosol Med 2007;20:13-8.

31. Hoffmeyer F, Harth V, Merget R, Goldscheid N, Heinze E, Degens P, Pesch B, Buenger J, Bruening T, Raulf-Heimsoth M. Exhaled breath condensate analysis: evaluation of a methodological setting for epidemiological field studies. J Physiol Pharmacol 2007;58(Suppl 5):289-98.

32. Quanjer PH, Tammeling GJ, Cotes JE, Pedersen OF, Peslin $\mathrm{R}$, Yernault JC. Lung volumes and forced ventilatory flows. Report Working Party Standardization of Lung Function Tests, European Community for Steel and Coal. Official Statement of the European Respiratory Society. Eur Respir J Suppl 1993;16:5-40.

33. Chai H, Farr RS, Froehlich LA, Mathison DA, McLean JA, Rosenthal RR, Sheffer AL, Spector SL, Townley RG. Standardization of bronchial inhalation challenge procedures. J Allergy Clin Immunol 1975;56:323-7.
34. Aberer W, Kranke B. Measurement of IgE antibodies using liquid allergens - an inter-method and inter-laboratory quality assessment. Wien Klin Wochenschr 2002;114:92937.

35. Dreborg S, Frew A. Position paper. Allergen standardisation and skin tests. Allergy 1993;48(Suppl 14):49-82.

36. Borrill ZL, Roy K, Singh D. Exhaled breath condensate biomarkers in COPD. Eur Resp J 2008;32:472-86.

37. Carpagnano GE, Kharitonov SA, Foschino-Barbaro MP, Resta O, Gramiccioni E, Barnes PJ. Increased inflammatory markers in the exhaled breath condensate of cigarette smokers. Eur Respir J 2003;21:589-93.

38. Montuschi P, Collins JV, Ciabattoni G, Lazzeri N, Corradi M, Kharitonov SA, Barnes PJ. Exhaled 8-isoprostane as an in vivo biomarker of lung oxidative stress in patients with COPD and healthy smokers. Am J Respir Crit Care Med 2000;162:1175-7.

39. Nowak D, Kalucka S, Białasiewicz P, Król M. Exhalation of $\mathrm{H} 2 \mathrm{O} 2$ and thiobarbituric acid reactive substances (TBARs) by healthy subjects. Free Radic Biol Med 2001;30:178-86.

40. Do R, Bartlett KH, Chu W, Dimich-Ward H, Kennedy SM. Within- and between-person variability of exhaled breath condensate $\mathrm{pH}$ and $\mathrm{NH} 4+$ in never and current smokers. Resp Med 2008;102:457-63.

41. Boulet LP, Lemiere C, Archambault F, Carrier G, Descary MC, Deschesnes F. Smoking and asthma: clinical and radiologic features, lung function, and airway inflammation. Chest 2006;129:661-8.

42. Effros RM, Dunning MB 3rd, Biller J, Shaker R. The promise and perils of exhaled breath condensates. Am J Physiol Lung Cell Mol Physiol 2004;287:L1073-80.

43. Brunetti L, Francavilla R, Tesse R, Strippoli A, Polimeno L, Loforese A, Miniello VL, Armenio L. Exhaled breath condensate $\mathrm{pH}$ measurement in children with asthma, allergic rhinitis and atopic dermatitis. Pediatr Allergy Immunol 2006;17:422-7.

44. Profita M, La Grutta S, Carpagnano E, Riccobono L, Di Giorgi R, Bonanno A, Pace E, Bonsignore G, Bousquet J, Vignola AM, Gjomarkaj M. Noninvasive methods for the detection of upper and lower airway inflammation in atopic children. J Allergy Clin Immunol 2006;118:1068-74.

45. Nicolaou NC, Lowe LA, Murray CS, Woodcock A, Simpson A, Ćustović A. Exhaled breath condensate $\mathrm{pH}$ and childhood asthma: unselected birth cohort study. Am J Respir Crit Care Med 2006;174:254-9. 
Sažetak

pH KONDENZATA IZDAHA U ODRASLE POPULACIJE HRVATSKE BEZ DIŠNIH POREMEĆAJA - KOLIKO ZDRAVA TREBA BITI POPULACIJA U KOJOJ SE UTVRĐUJU NORMATIVNE VRIJEDNOSTI?

Ciljevi preliminarnog istraživanja bili su izmjeriti $\mathrm{pH}-$ vrijednosti kondenzata izdaha (pH KI) odraslih stanovnika Hrvatske bez dišnih poremećaja te utvrditi kriterije potrebne za definiranje zdravlja dišnog sustava populacije u kojoj se planiraju utvrditi normalne pH-vrijednosti KI-a. U uzorku od 109 odraslih osoba bez tegoba od strane donjih dišnih putova, sužavajući definiciju "zdravlja", opisane su 4 skupine ispitanika: 1) bez donjih dišnih simptoma (DS); 2) bez gornjih i donjih DS; 3) bez DS i hiperreaktivnosti bronha s normalnim $\mathrm{FEV}_{1}$; 4) bez DS i hiperreaktivnosti bronha s normalnim $\mathrm{FEV}_{1}$, ukupnim IgE i s negativnim prick testom. Medijani $\mathrm{pH}$-vrijednosti nisu se razlikovali između skupina $(7,72 ; 7,73 ; 7,73$; 7,73), ali uvođenjem sve strožih kriterija zdravlja uočen je blag, iako nesignifikantan, porast minimalnih pH-vrijednosti KI-a $(6,95 ; 7,10 ; 7,20 ; 7,37)$. Medijan $\mathrm{pH}$ KI s interkvartilnim rasponom u ukupnom uzorku $(7,72 ; 7,63$ do 7,76$)$ bio je unutar raspona vrijednosti izmjerenih u istraživanjima drugih autora. $\mathrm{Na} p \mathrm{H}$ $\mathrm{KI}$ nisu utjecali spol, navika pušenja i atopijski status i nije bio povezan $\mathrm{s}$ dobi, vrijednostima $\mathrm{FEV}_{1}$ ili ukupnim IgE. Uočeni nesignifikantni trend porasta $\mathrm{pH}$ KI nakon uvođenja strožih zdravstvenih kriterija sugerira potrebu daljnjih istraživanja kriterija za definiranje zdravlja dišnog sustava na većem uzorku.

KLJUČNE RIJEČI: atopija, kožni prick test, kriteriji zdravlja, pH KI, pušenje, reaktivnost bronha, spol

\section{CORRESPONDING AUTHOR:}

\section{Veda M. Varnai}

Institute for Medical Research and Occupational Health Ksaverska cesta 2, HR-10001 Zagreb, Croatia;

E-mail:vvarnai@imi.hr 